\section{LA ILUSIÓN TEATRAL: SU CONSTRUCCIÓN DESDE LA ESCRITURA}

\author{
Miguel Nieto Nuño \\ Universidad de Sevilla \\ http://orcid.org/0000-0002-6808-9633 \\ mnieto@us.es
}

Cómo citar este artículo/Citation: Nieto Nuño, Miguel (2021). La ilusión teatral: su construcción desde la escritura. Arbor, 197(801): a612. https://doi.org/10.3989/arbor.2021.801002

Recibido: 14 abril 2020. Aceptado: 13 mayo 2021.

Publicado: 9 diciembre 2021

RESUMEN: La obra de Antonio Buero Vallejo titulada Un soñador para un pueblo sirve para ilustrar cómo la ilusión se apoya en elementos escenográficos y literarios. Retrocediendo hasta el Retablo de las maravillas de Cervantes, se observa cómo la ilusión no precisa más que de la palabra para producirse. La reflexión sobre el papel del actor y la palabra como causantes de la ilusión dramática conduce a discernir en el enfrentamiento entre Wagner y Nietzsche para comprender la emancipación del teatro como arte total alejado de la literatura. El teatro visual de finales del siglo XX esclarece la alternancia de fundamento retórico en el teatro literario (metáfora), performativo (imagen) y actual de retorno al texto (ironía). Se da resumida noticia de cómo la ilusión es concebida en el teatro oriental.

PALABRAS CLAVE: Ilusión, palabra, imagen, teatro literario, teatro visual, teatro actual, teatro oriental.

\section{THEATRICAL ILLUSION. CONSTRUCTION FROM THE WRITING PERSPECTIVE}

Copyright: () 2021 CSIC. Este es un artículo de acceso abierto distribuido bajo los términos de la licencia de uso y distribución Creative Commons Reconocimiento 4.0 Internacional (CC BY 4.0).
ABSTRACT: Antonio Buero Vallejo's work entitled Un soñador para un pueblo serves to illustrate how the illusion created is based upon staging and literary elements. Going back to Retablo de las Maravillas by Cervantes, it can be seen that, in order to create an illusion, one does not need more than the power of the spoken word. Reflection on the role of the actor and their interaction with the spoken word to create dramatic illusion leads to distinguishing the confrontation between Wagner and Nietzsche in order to understand the emancipation of theatre as a total art, distant from literature. The visual theatre of the late twentieth century highlights the changing of the rhetorical background in literary theatre (metaphor), performative (image), and the current return to the text (irony). A summation of how illusion is conceived in Eastern theater is given.

KEYWORDS: Illusion, word, image, literary theater, visual theater, current theater, Eastern theater. 


\section{LA ILUSIÓN TEATRAL}

Desde que escribí, hace dos décadas, un estudio sobre la adaptación cinematográfica de Un soñador para un pueblo, me ha venido persiguiendo la intención de volver sobre esta obra de Buero Vallejo, que no es de las más estudiadas entre las de su producción (Nieto Nuño, 1998). Las urgencias de la carrera académica me han impedido hacerlo. Recuerdo ahora este drama histórico, pues me parece apropiado para estudiar la relación indisoluble entre la idea del teatro y el concepto de ilusión. El teatro es ilusión, y la ilusión escenografía (Álvarez Romero, 2015: 63). Esta afirmación resulta de todo punto pertinente para introducir el análisis de Un soñador para un pueblo, aunque reducida a silogismo derive en conclusiones incompletas y por consiguiente falsas. En cualquier caso convendría acompañarla de esta otra sentencia: el teatro es emoción, y si no hay emoción no hay teatro; que escuché a José Luis Alonso de Santos en un encuentro con el público asistente a la función de su obra En el oscuro corazón del Bosque, que él mismo dirigió ${ }^{1}$ Espero llegar a esta última, partiendo de la primera, al final del estudio.

Un soñador para un pueblo es una obra muy innovadora. La innovación comienza con la máquina escenográfica que dispone Buero Vallejo en una acotación de esmerado detalle. El escenario acoge en el proscenio una plaza de Madrid, que se prolonga por los laterales y eleva una casa de un piso, con balcón practicable. Ocupando la parte central del foro, una plataforma circular ofrece a la vista del espectador cuatro estancias de distintos palacios, según gira. Al fondo, junto a la casa de barrio, un ventanal orientado hacia las bambalinas permitirá a Esquilache tender su vista a la plaza para contemplar cuanto el espectador presencia en primer plano. Imagino el esfuerzo del público madrileño por semantizar la mirada, sorprendida y expectante, ante una perspectiva espacial tan audaz para aquellos tiempos. Sin duda sentiría la necesidad de devolver a lo posible lo que la percepción y la razón declaran imposible: contemplar a la vez y sobrepuestos un fijo paisaje urbano y cambiantes interiores de alejadas casas. La propuesta escénica no pretende engañar los sentidos; demanda, bien al contrario, que la imaginación opere en sentido contrario a la información que transmiten, construyendo una ilusión que dé sentido a lo irreal, a lo imposible percibido, de manera análoga a como la pintura cubista obliga a reconstruir la perspectiva que la imagen en su único plano niega. La realidad así producida se sobrepone a lo real.

Este juego por el que la ilusión, al fondo de las percepciones, produce los espacios de representación se advierte con toda claridad en un momento del desarrollo dramático. Esquilache se acerca a la ventana para observar la revuelta tramada a las puertas de su palacio. Su mirada se aleja de las de los espectadores en ángulo agudo. Sin embargo, en un punto ideal confluyen sobre la escena desplegada en primer plano. Ese punto ideal que absorbe las perspectivas visuales es, nuevamente, una geometría imaginaria que requiere del autor un saber hacer, y del público una determinada competencia interpretativa.

En función del espacio, el tiempo narrativo sacrifica su secuencialidad inevitable para contraerse, como el mismo plano escénico, en simultaneidades veraces. Contemplamos la confabulación que se apresta en la plaza al tiempo que asistimos a las conjuras políticas tejidas en los interiores de los palacios. Se dota así al teatro de medios para contar la historia con una solvencia de la que otras narraciones -literarias o audiovisuales- carecen, que remueven eficazmente el compuesto emocional formado por símbolos y verdades poéticas. Así, al final de la primera parte del drama, Esquilache, abandonado por todos -menos de Fernandita- $y$ a punto de ser sacrificado por Carlos III, confiesa: «somos como niños sumidos en la oscuridad»; al momento en que en la calle prende el alumbrado público que él había auspiciado, y la plaza se puebla de espías embozados. La realidad en la sala es que lo que se dicen Esquilache y Fernandita han de oírlo necesariamente los personajes apostados en el proscenio, incluso antes que el público por la cercanía, pero la verdad dramática la vuelven a establecer los espectadores, que tienen ojos para compartir la intimidad de los protagonistas, y ojos también para presenciar los prolegómenos de la revuelta. Se desvela así la verdad de unos personajes a la que no tiene acceso el populacho, y se manifiesta, asimismo, la relación engañosa entre lo real y sus apariencias. Los personajes no solo se despegan de sus limitadas condiciones dramáticas -se salen, por así decirlo, del cuadro como sucede en la posterior obra Las Meninas-, sino que se elevan por encima de las personalidades históricas.

El planteamiento escenográfico de Un soñador para un pueblo rompe con la ilusión realista que parece consustancial al género trágico desde sus orígenes

1 En la sala Max Aub del Teatro Español, sede del Matadero, el 29 de marzo de 2016. 
históricos (Gil Fernández, 2012: 25)². En esta obra no es la apariencia la que suscita el engaño perceptivo que origina el juego de las identificaciones, necesario para el efecto final de purificación; la escenografía guía aquí una interpretación intelectual que corrige la imitación, paradójicamente irreal, de lo real (Gombrich, 2008: 170-177)3. Crea las condiciones para que la ilusión enmiende en su proceso receptivo de resignificación la percepción de lo real. Solo en la ilusión es posible el conocimiento y la esperanza, parece querer decirnos el autor. De no andar desacertado en esta conclusión, podría finalmente añadir que la ilusión es hija de la razón, y se vierte desde la subjetividad sobre lo real para construir el objeto de la comprensión. En lo real no hay objeto alguno, repetiría uno más entre los seguidores de Schopenhauer, pues «la objetividad no es más que un sólido efecto ilusorio dentro de la subjetividad» (Parmeggiani, 2003: 54). Así, la escenografía teatral, con su reducción retórica, quedará subsumida hasta su desaparición en el completo escenario de la representación que cada sujeto internamente despliega, y que seguramente se tornará reconocible tan pronto abandone la sala del teatro y sus pasos le lleven por las encrucijadas de la vieja ciudad. También en Un soñador para un pueblo puede avistarse el germen del llamado efecto de inmersión, consagrado en El concierto de San Ovidio, que entraña tanto una reducción de la perspectiva como un tratamiento extremado de la ilusión para el espectador.

La ilusión es una condición originaria del teatro, que no precisa de escenografía o bien la genera tan pronto como se desencadena el fenómeno de la representación. Si hay lugar volveremos a ello al referirnos a la corriente antropológica desarrollada en las últimas décadas del siglo pasado. La simple palabra encaramada a un escenario inexistente basta para que se desencadene. En el entremés cervantino El retablo de las maravillas una pobre compañía de cómicos se encamina hacia cierta población. No hay camino, ni población, ni paisaje, ni siquiera indicación alguna de movimiento. Los vemos, a los cómicos, pero sobre todo los oímos, y porque los oímos sabemos que están en acción. Esto mismo sucede en el teatro clásico oriental, donde la prescripción de nuestras unidades dramáticas es completamente desconocida, pues la acción representada desborda las posibilidades de cualquier escenario. Pero un largo viaje por paisajes inmensos se puede realizar y contemplar en el corto tiempo que dura un aire musical. Así, por ejemplo, en la obra de Historia del ala oeste, de Wang Shifu, escrita tres siglos antes que la cervantina:

«Caminando, caminando he llegado al paso $\mathrm{Pu}$, el río Amarillo tiene nueve recodos, esta es la antigua región de Henei iqué maravilloso paisaje! ¿Dónde asoman las ondas del viento de los nueve recodos? Si hay un lugar tortuoso, este debe ser. Este río abraza Qi y Liang, divide Qin y Jin, separa You y Yan, olas de crestas nevadas baten el vasto cielo, se enroscan nubes otoñales en los confines del firmamento: los tallos de bambú se confunden con el puente flotante y sobre el agua se sumerge el dragón azul. A este y oeste se inundan las nueve regiones, de norte a sur se ensartan cien ríos. Una barca de regreso sin prisa, ¿cómo verla?, cuando de pronto, como una flecha, abandona su arco. Parece que el río de plata descendiera de los nueve cielos suspendido de los profundos manantiales más allá de las nubes. Para entrar en el Mar del este debe atravesar por aquí. Baña las mil especies de flores de Luoyang, riega los diez mil campos cultivados de Liangyuan y una vez arrastró una barca hasta los confines del sol y de la luna. Mientras cantaba he llegado a la ciudad. Hay una posada (etc.)» (Wang, 2002: 184-185).

A vista del espectador en escena solo hay un estudiante con su fámulo, que canta: una fusta sirve por un caballo, un remo por una barca. La totalidad de la secuencia y de las imágenes se confía a la palabra reforzada por la mímica.

El fantástico retablo cervantino posee todavía menos realidad que estos adminículos portados por el aspirante a mandarín. Los cómicos Chirinos y Chanfalla fían a su locuacidad y garambainas el poder de sugestión que hace surgir en las crédulas mentes lugareñas la figura bíblica de Sansón, a la que sigue un toro de lidia famoso por su brutalidad, una manada de ratones que ponen en dificultades a las mujeres, aguas procedentes de las fuentes del Jordán, etc. Los rústicos quieren ver cuanto los cómicos les describen por no pasar por conversos o bastardos. Solo el gobernador, sumido en la perplejidad, disimula ver, porque duda. Sus dudas no le salvan de la ilusión, pero sí abren las puertas de la certidumbre al público del entremés. Las prometidas maravillas no son tales, sino los fantasmas de la mente a los que las palabras de los cómicos procuran imagen con su charlatanería. El re-

2 Donde al mismo tiempo califica a la comedia por más real.

3 Ernst H. Gombrich se sirve del concepto de proyecciones guiadas. 
tablo maravilloso es un teatro mental cuyas imágenes en latencia ocupan el vacío espacial para mudarlo en espacio dramático, convirtiendo "en realidad la nada» (González, 2007: 208).

El público que asiste a la función no tiene acceso a esos teatros mentales cuyo único autor, finalmente, es cada uno de los personajes. Si la interpretación fuera suficientemente expresiva para borrar toda impresión de fingimiento, se contaminaría la comprensión del público de temor y respeto por la amenaza de acusación que domina el contexto social. Pero no debe ser así, y la teatralidad debe ser claramente discernible. Huye Cervantes de fijar una verdad dramática como sí fija Shakespeare mediante la estructura en abyme. Cervantes prefiere la suspensión irónica a la mostración. La verdad queda en su teatro desplazada y a merced de la sutileza del espectador. Pues al igual que al público del retablo se le ha concedido el protagonismo de su propia representación mental, también al público del entremés le otorga Cervantes la posibilidad de reconocer que en su mente se han sucedido tiempos y espacios ilusorios, se han erigido fantasmas bajo las resonancias de su memoria. Es la memoria la que crea un espacio más amplio que el de la representación, donde el espectador convoca sus experiencias encarnadas en los personajes de ficción que tiene a la vista para componer un nuevo aprendizaje sobre la realidad (Bologna, 2017: 44). Ahora nuestra superioridad histórica nos concede tal vez la sonrisa al contemplar la ingenuidad de aquellos lugareños de ficción, pero en la época de Cervantes el destinatario de la función teatral cabe imaginar que no se sentiría tan lejano de aquellos simples paisanos que disimulaban por no quedar señalados, y que la risa se la arrancaría también un recelo semejante experimentado en algún momento de su vida.

El retablo de las maravillas es un juguete cómico, al que tal vez no quiso imprimir Cervantes mayor trascendencia, como quiere Eugenio Asensio ${ }^{4}$. En sus comedias aspira a mayor arte, y por ello recurre a la ilusión generada por la confusión de identidades, prácticamente inexistente en nuestro entremés (Teixeira de Souza, 2018). En estas obras de mayor extensión, la ilusión está al servicio de la intriga, se presta al juego de inversiones y por ello es entendida como un recurso fundamental para el desenvolvimiento del argumento dramático. En El Retablo, en cambio, la ilusión deja de ser un recurso para constituir lo medular de la representación. $\mathrm{Y}$ aunque breve y respondiendo a la sola intención de procurar entretenimiento, no puede desentenderse del estilo de su autor, esto es, del fondo de imaginación determinado por sus experiencias vitales y por su pensamiento forjado en el curso de la historia. En las manifestaciones de sus personajes, en sus conductas, resulta inevitable para Cervantes indagar en lo recóndito del ser humano, que se expresa no pocas veces como locura. Imaginaciones escondidas en el alma, que abren paso al conocimiento, pero también al extravío. Esta clase de imaginación es la que preconiza Ignacio de Loyola en sus ejercicios espirituales, en los que la mente debe disponer un espacio escénico presto a la sacra representación. $Y$ en dicho espacio creado por la memoria, las imaginaciones adquieren su energía por transferencia de los contenidos lingüísticos que conforman la mente. La imaginación proyecta al exterior dichos contenidos como imágenes cargadas de conocimiento. Es muy probable que Ignacio de Loyola tomara estas ideas de Giulio Camillo, para aplicarlas al propósito de su devoción (Bologna, 2017: 165). Giordano Bruno, seguidor de Camillo y estricto coetáneo de Cervantes, calificaba de mágicas estas imágenes que vierten en expresión el sustrato profundo de la mente.

Son éstas ideas auspiciadas en tiempos de Cervantes por círculos selectos, donde una abstracción del teatro adquirió alto valor simbólico, que se extendería a la comprensión general de la existencia. En todo caso, la representación del Retablo podría entenderse como un ejercicio ignaciano llevado al extremo del ridículo, como una prevención contra un exceso esotérico del conocimiento. Antes de desplegar su función, los cómicos habían retratado al autor del Retablo como un viejo nigromante, acaso italiano pues lo bautizaron Tontonelo, de luengas barbas hasta la cintura. Tontos habrán de ser quienes se dejen seducir por tan falso autor, a quien tanto por el estereotipo como por su lejana procedencia conceden toda admiración y credibilidad los cándidos lugareños. Como lo que escuchan coincide con sus imágenes mentales no advierten la patraña, ni reparan en lo burlesco del nombre. La risa interna de los comediantes coincide con la externa que se supone en el público. Pero éste no está interesado en el negocio de los cómicos, lo que le permite superar la perspectiva interna de la obra y orientarse hacia el recto entendimiento. De este modo, concluimos, el Retablo resultaría, además de un divertimento y una ridiculización de los valores sociales imperantes, un irónico alegato contra la ilusión como proceso de conocimiento y, consecuentemente, contra la ficción teatral, a la que, sin embargo, se mima. Aun

4 Sobre el alcance de los entremeses cervantinos véase el citado trabajo de Aurelio González (2017: 207-208). 
sin pretenderlo, se trasluce en este juguete dramático el desencanto característico en Cervantes que desemboca en la barroca actitud de desengaño.

Entender así El Retablo de las maravillas proyecta el pensamiento de Cervantes hasta el siglo XIX, cuando se produce una de las polémicas más intensas de los tiempos modernos en torno a la ilusión teatral. Apoyándose en la reflexión kantiana, el Romanticismo se erigió sobre la ilusión trascendental básica de la subjetividad. Desde su raíz, la ilusión traspasa la totalidad del movimiento romántico hasta su epígono encumbramiento en la obra operística de Richard Wagner. Si en el Renacimiento el teatro había inspirado la pretensión abarcadora del conocimiento, con Wagner se califica como suma de la creación. Desde la cima el teatro irradia el poder que forma el espíritu de un pueblo. El actor se confunde con el poeta, aquel que presta voz a un pensamiento compartido por una comunidad que da origen a una nación. Para Wagner el actor, el mimo «se identifica completamente con la expresión del fondo vital, es su inmediata transparencia, por lo que la veracidad es el fundamento del arte del mimo» (Campioni, 2007: 44). El movimiento nacionalsocialista no hay duda que encontró su inspiración en la teatrocracia wagneriana, y confirió a su líder el aura de artista supremo como actor.

Nietzsche no pudo prever que la ilusión habría de desembocar en tan apocalíptica catástrofe como ha soportado la humanidad en el siglo XX, pero sí aseguraba que nada con ansia de permanencia puede confiarse a ella. El nacimiento de la tragedia, que había acogido Wagner como un refuerzo estético de su grandilocuencia romántica, sirvió a su autor para contrarrestar la enorme energía generada por el drama wagneriano. La sublime creación del actor queda reducida en su mirada a imitación simiesca, visión difundida posteriormente por el cinematógrafo a propósito del líder nacionalsocialista. Ningún conocimiento puede extraerse del arte de la actuación, que es puramente efectista. Y donde se busca el efecto se pierde la verdad. "Il faut être sec, clair, sans illusion», afirmaba Stendhal y repetía Nietzsche. Así que, por fuerte que pueda parecer la extrapolación, en Chanfalla, el cómico cervantino, se puede atisbar el ilusionismo wagneriano, que calificaba Nietzsche como genio de la mentira; mientras que en el personaje final del furrier, desencantador de la magia escénica, podría vislumbrarse el genio de espíritu dio- nisíaco, que se atiene al principio de corporalidad como verdad. Por oponerse a la decadente sublimación de la genialidad wagneriana, acabó Nietzsche por negar el teatro. Veía en su encantamiento la letárgica suspensión de la voluntad, como antes y por críticas semejantes lo había condenado Rousseau (Fischer-Lichte, 2011: $382)^{5}$. Solo el estudio y la reflexión podían provocar, a su entender, la metamorfosis que el teatro falsificaba mediante una simplificación ilusoria.

Tan vacío como concebía Cervantes el espacio escénico para su Retablo lo descubren los nuevos artistas del siglo XX, los escenógrafos. Mediante la palabra el vacío se transformaba entonces en espacio dramático. Como en aquellas sencillas representaciones que contrastaban expresivamente con el boato de las escenografías simbólicas de las cortes europeas, los escenógrafos del siglo XX rehúyen el concepto de decorado. Ahora el vacío se les representa como un lienzo en blanco, o como espacio pendiente de plástica composición. La misma empresa teatral, que ve recortadas sus fuentes de ingresos en competencia con el naciente cinematógrafo, se ve impelida a la simplificación por abaratamiento de las producciones, y seducida también por el impacto de las nuevas imágenes cinematográficas que moldean una nueva captación y sensibilidad en los públicos. Se produce así una sorprendente síntesis entre las tesis postuladas por Wagner y las replicantes de Nietzsche, que habían sido dadas por irreconciliables. De éste conserva el arte escénico el sentido de materialidad, al que contribuye de manera decidida el estudio de la luz, como en el mundo del barroco, posibilitado ahora por el dominio de la electricidad. De las ilusiones wagnerianas perdura la aspiración a un arte total reunido sobre el escenario, espacio del que se va expulsando, paradójicamente, a la fuente original de la ilusión, la palabra. La historia del teatro en el siglo XX podría comprenderse bajo un desarrollo dialéctico entre la predominancia de escritores y actores, por un lado, o de directores y escenógrafos, por otro. Subyacente a esta tensión, que no pocas veces adquiere el tono de rivalidad artística, discurre aquella otra tensión más profunda entre materialidad e ilusión, cristalizada sobre los escenarios como presentación o representación ${ }^{6}$.

La controversia, que alcanza nuestros días, eclosionó pocos años después del estreno de Un soñador para un pueblo. En la década de los años sesenta del

5 De la aversión de Rousseau por el teatro se alimenta irónicamente la polémica con Voltaire en la obra de Jean-François Prévand Voltaire / Rousseau: la disputa (2018).

6 Erika Fischer-Lichte (2011) emplea el término realización escénica en contraposición con el de representación. Esta obra es la que sigue la exposición en las próximas líneas. 
siglo pasado irrumpieron distintas corrientes que modificaron radicalmente el concepto teatral y la relación del público con la escena. El teatro de base literaria no ha dejado de existir, y a diferencia de lo que ha sucedido en otras artes, como la música, no ha perdido ni la capacidad de expresar su tiempo ni de comunicar con el público. Pero lo cierto es que ha tenido que compartir espacio con un teatro en que la autoría se ha desplazado del dominio de la palabra al dominio de la escena, y donde la función se concibe como acontecimiento espectacular antes que como representación. A la conjunción de artes plásticas -pintura, pero también escultura- con el arte arquitectónico se han sumado nuevos componentes estratégicos: la performance, la instalación, el videoarte y el ritual:

«Las artes plásticas pueden ser teatrales pero no por ello son ningún teatro. El teatro puede mostrar imágenes, pero no por ello son artes plásticas. Son dos disciplinas diferentes con una historia distinta. Ambas requieren un método de trabajo completamente distinto. Todo influye en todo. Y de este contagio pueden surgir visiones. Mediante las artes plásticas una interpretación nueva del teatro y viceversa [...] El teatro necesita la mentalidad del arte de la performance. Esta mentalidad lijará los límites entre ilusión y realidad. Surgirá una herida erosiva sobre la que echaré con mucho gusto sal. [...] Les he entregado a los actores y bailarines copias de obras maestras clásicas y modernas. Deben improvisar a partir de esas pinturas. Les agudizará la imaginación los próximos días y les hará ser conscientes de la relación que existe entre las artes plásticas y el teatro. Deben estudiar las posturas corporales, la puesta en escena, la luz y la dramaturgia de los cuadros y traducir todo eso a la escena» (Jan Fabre en Diario nocturno, 2017)7.

En gran medida toda la novedad de este teatro gravita sobre el arte de la actuación, que no de la interpretación como había sucedido hasta los tiempos de Nietzsche. Tanto como Rousseau, Wagner detestaba la escuela de la comédie française. No solo por lo que aducía Rousseau: la falsedad de la actuación y la mercantilización de su arte ${ }^{8}$, sino porque la interpretación afectada impedía toda transparencia del fondo vital que el artista romántico aspira a expresar. En las representaciones populares, como la cervantina, sí ad- vertía Wagner esa plenitud de la mirada que origina la ilusión del genio, sustitutoria de la ilusión sacra. Cierto es que el naturalismo que sucede al movimiento romántico descree de dicha ilusión, pero la transforma bajo el ideal estético de la encarnación. El teatro de Chéjov reclama vivamente al personaje, necesita que el espectador se deje inducir a contemplar en la corporalidad del actor -su bulto, su voz, sus gestos- el espíritu alojado en las palabras previstas por el autor para el personaje. La aceptación de la ficción dramática depende de esa ilusión que parte de la habilidad del actor para hacer brotar de su organismo el personaje. Nadie pone en discusión a día de hoy la vigencia de esta idea, que las necesidades de la industria cinematográfica han convertido poco menos que en una kantiana ilusión trascendental.

«El actor es precisamente un mono ideal, y mono hasta tal punto que no puede crear en absoluto en la esencia o en lo esencial: para él todo es juego, sonido, gesto, escena, escenario y público»; así respondía Nietzsche a la valoración sublimada del arte de la interpretación que preconizaba Wagner (Campioni, 2007: 46). Justamente cuanto denigraba Nietzsche es lo que aprecian los autores-directores del presente para materializar la actuación teatral y librarla de toda ejecución ilusoria. Ignoro si Jan Fabre conoce la cita anterior. Pero en todo caso sus anotaciones diarias revelan un pensamiento sorprendentemente concordante con el de Nietzsche:

«Un bailarín brillante en el cuerpo de un mono que siempre improvisa. Un cuerpo que habla como nosotros hablamos con repeticiones y vacilaciones. Un cuerpo que muestra pura y detalladamente los movimientos impuros. Un cuerpo con una memoria del movimiento y unos reflejos de la danza norteamericana contemporánea. Un cuerpo como una banana musculosa y flexible que te gustaría devorar. Steve Paxton es ese mono. Él mismo ha comido muchas de esas bananas» (Fabre, 2017: 157).

Pero Jan Fabre no está pensando en el mono ideal de Nietzsche, que se torna carne de escenario en la obra posterior de Franz Kafka. La cita de Fabre hay que encuadrarla en los espectáculos de performance como los de Joseph Beuys, Marina Abramovic o el mismo

7 La primera anotación corresponde al día 5 de junio de 1984 (Fabre, 2017: 207); la segunda al día 5 de agosto de 1980 (Fabre, 2017: 65 ); la tercera al 5 de abril de 1984 (Fabre, 2017: 200).

8 «¿Qué es un cómico sino alguien que domina el arte de parecer diferente de lo que es, y de decir cosas distintas de lo que piensa? ... ¿Qué es la profesión del actor sino un oficio por el que pone su propia persona en venta?», le hace decir en la obra citada Jean-François Prévand (Prévand, 2018: 36). 
Fabre, en los cuales la presencia de animales conduce a la naturaleza humana a una experiencia elemental y límite. Si en el teatro anterior lo que importaba era el personaje, en el nuevo teatro visual que empieza a perfilarse en los albores del siglo XX el actor atrae el foco de atención sobre sí mismo, en ofrecimiento de su propia imagen. El actor se muestra con toda su dinámica corporal como actor -así no pudo imaginarlo nunca Rousseau, acaso como sí pudo Nietzsche, como hipóstasis del espíritu dionisíaco-, y con todo su poder creativo -como quería Wagner- que justifica su manifestación ante el espectador. Cometido del actor ya no es prestar perceptibilidad a un fantasma cuyo origen, para el espectador, no es siquiera un conjunto de palabras sino que parece creación necesaria del mismo espacio escénico. Su cometido es justificar su manifestación sobre el escenario mediante el despliegue de su energía más elemental. Sobre el escenario es un hombre que se manifiesta como actor, pues el encauzamiento de su natural energía le permite la transformación, la metamorfosis. «Un actor no interpreta ningún papel. Él se crea a sí mismo. Él crea a un actor, que en una representación conquista su lugar. $Y$ es un lugar que él conoce a la perfección" (Fabre, 2017: $136)^{9}$. "Observo al actor, observo su cuerpo, escucho su voz y entonces intento hacer la obra con él», confiesa Robert Wilson (Fischer-Lichte, 2011: 172).

La investigación del autor-escritor creadora de personajes se ha convertido en la búsqueda emprendida por el autor-director de actores de singular energía que puedan asumir las ideas de su propia creatividad. Son expresivas las referencias que estos autores dejan de sus actores principales:

"Creo que he descubierto a alguien especial. Es pequeña, delicada y un poco rígida. Pero tiene un cuerpo increíblemente fuerte. También posee una extraña fuerza alquímica en los ojos. Parece como si fuera capaz de desplazar objetos con la mirada o pudiera prender fuego a las personas. Su nombre es Els Deceukelier (¿un instrumento para hacer que funcionen mejor los jugos gástricos?). Cuando la veo en acción me entra hambre. [...] Els Deceukelier se mueve por el escenario como un diablillo erótico. Pero cuando se detiene, siempre con los piececillos unidos, parece que es un casto angelito. Ella encarna la dualidad y la lucha entre el ser angelical y diabólico que debería ser un actor» (Fabre, 2017: 131 y 159) ${ }^{10}$.
«Miren, en una actriz como Christine Oesterlein los ojos son de una fuerza expresiva tal, incluso cuando apenas se mueve, que estremece y llega a lo más hondo [...] A veces, simplemente ahí sentada, tiene tanta fuerza... pocas personas son capaces de lograr algo así en escena» (Fischer-Lichte, 2011: 173).

La misión que se encomienda al actor ya no es la de proyectar sobre el público como una ilusión de realidad tangible un ser humano sin existencia. Se ha llegado a asumir el mismo desengaño que el de un niño que persigue las volátiles pompas de jabón. Si el espectador se acercara al actor por tocar al personaje, este se desvanecería, de igual manera que la pompa, sobre la piel de su portador. Por eso la interpretación en este teatro visual no tiene sentido:

«Mi responsabilidad como artista es crear, no interpretar. Lo cual resulta cierto tanto en mi trabajo en las artes visuales como en teatro. Ahora estoy trabajando en La flauta mágica y les digo esto a los cantantes todo el tiempo. Es algo muy confuso para ellos porque están acostumbrados a que deben interpretar sus papeles y actuar de forma naturalista con razones psicológicas para todo. Creo que la interpretación la debe hacer el público, no el actor, el director o el autor» (Valiente, 2000: 62).

Faltándole el trasfondo interpretativo, todo cuanto emana del actor, incluso la palabra, se remite a la imagen que compone su presencia en conjunción con otros elementos y espacios dispuestos en la escena. El arte del actor se torna arte de la figuración para la pintura animada que persigue el espectáculo teatral. En un grado ascendente de despersonalización puede pasar de alojar en su interior al mismo autor-director que lo manipula según sus intenciones, a convertirse en un objeto mediante la inmovilidad, de la que hace gala Wilson, o bajo la emulación de los maniquíes -ya descubiertos desde los primeros tiempos de la primera vanguardia- como preconiza Kantor en su afán de vaciar hasta la nada la realidad escénica:

«La vida, en el arte, solamente puede expresarse mediante la ausencia de vida, mediante el recurso a la muerte, al vacío, a la ausencia de todo mensaje. Por eso el maniquí, que encarna y transmite un sentimiento de la muerte y de la condición de los muertos, se convierte en un modelo para el actor vivo» (Valiente, 2000: 62).

9 Anotación del 5 de septiembre de 1982.

10 Anotaciones del 27 de julio de 1982 y del 14 de mayo de 1983. Todavía hay más asientos sobre esta actriz en el diario. 
El actor retorna así al integrante del coro griego despersonalizado. En su diario Jan Fabre se refiere a sus actores como «máquinas de sangre» alguna que otra vez, y más reiteradamente como «mis guerreros de la belleza».

No muy posterior a Un soñador para un pueblo, el teatro visual de las últimas décadas del siglo XX desencadena una reacción contra la ilusión por seguir, consciente o inconscientemente, los postulados de Nietzsche esgrimidos contra la teoría y la práctica teatral de Wagner. El actor ha quedado reducido a un peón escenográfico, cuando no a un simple muñeco animado. Si se le confían palabras, no es para que las rumie en las sombras de su memoria, sino para que emita sonidos que emplasten en color y textura con la composición escénica. Esto es lo que pretende Robert Wilson al escenificar los sonetos de Shakespeare. Despojados de su memoria, los versos de Shakespeare se transforman en pura resonancia de las imágenes que los portan. En el teatro literario la palabra es la primera fuente de ilusión, pues en su reconocimiento por el espectador es compartida. Hay, como en la obra de Buero Vallejo, interiores y exteriores, que fluyen para verterse unos en otros. La palabra domina el espacio escénico y se interna en la conciencia del espectador, donde remueve su memoria -en primer término lingüística- para abrir la posibilidad de una proyección imaginativa. La ilusión es una proyección subjetiva sobre la posibilidad: posibilidad de ser como otro, de descifrar las vivencias con claves distintas, externas aunque interiorizadas para expandir el reconocimiento. La palabra remite a la palabra, y en esa remisión se abre una posibilidad incesante de relacionar y resemantizar el mundo con cuantos participan de ella. Por esa razón el teatro es un arte social. Pero cuando la palabra es arrebatada a su propio légamo y a su propia memoria para desplazarla hacia la imagen por toda remisión, la capacidad de abrir el escenario de la memoria donde anida la ilusión queda cercenada. El mundo ya no es sino lo dado. «iÉse es el proceso de DESINTEGRACIÓN DE LA ILUSIÓN, y la única posibilidad de reencontrarse con la REALIDAD», afirma Tadeus Kantor (2010: 66) ${ }^{11}$ para quien, haciéndose eco del teatro político de Brecht, el fomento de la ilusión mediante el arte dramático entraña una grave irresponsabilidad social. Sin duda la experiencia histórica fue determinante en el forjado de sus opiniones.

Tal vez tenga razón Jan Fabre cuando afirma que «las palabras no empiezan como palabras» (Fabre,
2017: 196$)^{12}$. Anteriores son las ideas, si se admite que puede haber ideas antes de su pronunciamiento lingüístico, y las acciones. El teatro visual persigue la retracción de ese momento original, que no solo se remite a los inciertos inicios históricos del teatro como rito, sino que persigue la impermanencia de la impresión, de modo que se extinga antes de que la palabra la introduzca en el tiempo de la explicación. Por eso, en la búsqueda de la palabra anterior a la palabra, el teatro visual ha retornado a la naturaleza como larga invocación ritual. Se inspira en los chamanísticos rituales nuoxi que se practican desde tiempos inmemoriales en las regiones sureñas de China para celebrar el año nuevo, y duran tantos días como la visita de los dioses que descienden para procurar buenas cosechas. Allí, las palabras deformadas por las máscaras sagradas son originarias de la oración y el habla, que primero se expresan mediante ritmo y danza. Pero si el teatro ritual chino concluye en la palabra del hombre que agradece la visita y los cuidados divinos, en el teatro de Wilson o Fabre no se aspira a la fundación del lenguaje. La operación metafórica que da naturaleza a la palabra implica un desplazamiento espacial, al relacionar un objeto con otro objeto, lo que entraña transcurso temporal. La escritura china es la que mejor expresa esa condición esencial de la palabra, pues en ella el mundo se refleja en transformación, en cambio. La ilusión resulta de esa misma operación como proyección mental. Pero el teatro visual pretende relacionarse con la belleza de manera inmediata, prescindiendo de la metáfora. Anteriores a la palabra son las puras percepciones de los sentidos. Y la palabra, antes que significado es percepción. La simple recepción de la palabra debe conducir a una experiencia límite, sin significación, vinculada a la imagen. La palabra negada al actor, y su interpretación también negada, aproximan la actuación a la acción del performista, en busca de romper la membrana que vincula el lenguaje con la realidad.

«La vida social de las cosas, las imágenes y los sujetos, ya no se reconoce en una economía de la representación erigida en torno al dualismo de lo falso y lo verdadero, de la esencia y la apariencia, de lo real y lo virtual, sino en la problematización de esas relaciones bajo paradigmas complejos» (Martínez Luna, 2016: 107).

11 Fischer-Lichte (2011: 67) recoge el testimonio de Alfred Klaar después de presenciar la representación de la Orestiada, en versión de Max Reinhardt (1911), donde describe los procedimientos que dan por resultado la extinción de la ilusión.

12 Anotación del 27 de febrero de 1984. 
Quizá el giro hacia la visualidad del teatro haya que entenderlo bajo tal premisa. Las imágenes, afirma Baudrillard (2006: 28) han renunciado a la reflexión para instituirse como cosas; y entre las cosas se inscriben como mudas figuraciones, así los actores en escena como figurantes sin palabra. Las imágenes a las que se incorporan deslumbran con su evidencia, pero se agotan en su mismo resplandor. Es lo que podría predicarse de la experiencia límite de la performance. No se deja traspasar, pues carece de tiempo. Mantenerse en el destello es lo que Fabre denomina éxtasis (Fabre, 2017: 163) ${ }^{13}$. Su aspiración, si acaso, consiste en provocar la reacción ${ }^{14}$. Pero el mismo efecto deslumbrador anega toda posibilidad de secreto, que es de donde parte, al decir de Baudrillard, la ilusión. Y la mirada se agota.

La constatación de la imposibilidad -o el agotamiento de lo maravilloso- cursa el desengañado retorno del mundo, que en el escenario vuelve a expresarse por la palabra. Y con ello retornan las claves simples del teatro cervantino, después de haber traspasado nosotros la metáfora escénica de Buero Vallejo y de habernos detenido en los límites irracionales -e infranqueables- de la imagen. La ironía es la que nos permite seguir aceptando el teatro visual y el teatro literario sobre los mismos escenarios, bajo la misma denominación como espectáculo singular o complejo. "La ironía como forma universal y espiritual de la desilusión del mundo» (Baudrillard, 2006: 29). Tal vez venga la palabra a dotar de tiempo, es decir, de la permanencia necesaria para generar reflejos, a la acción instantánea que del éxtasis se derrumba en lo profano ${ }^{15}$. Esto sucede en el nuevo teatro de Angélica Liddell, donde la palabra salva el instante de la acción bruta, para acoger el éxtasis en la relación desengañada con el mundo como una posibilidad para la inmanencia que concierne al ser humano. Solo en lo que la conciencia se experimenta concernida puede brotar la ilusión.

Por eso la afirmación con que arrancaba este trabajo (el teatro es ilusión y la ilusión escenografía) solo sirve parcialmente para comprender cómo se provoca desde el escenario la ilusión, y dónde desemboca.
Para aceptarla es preciso contemplar la actitud concernida del público. Si no se activa el interés, la proyección subjetiva es imposible y el escenario enmudece. Y el interés es en sí mismo una emoción. Respecto a la comunicación emocional que vincula el suceso de la obra con el interés del público nos ahorraríamos intrincadas descripciones si la denomináramos con un término concreto como el japonés hara, que significa flor. La evocación de la flor evidencia la emoción que ha de suscitar una representación del teatro ritual noh. Todos los elementos que intervienen en la representación -hasta los guturales sonidos articulados que no alcanzan a ser palabras (kakegoe)- han de estar traspasados, como un perfume, por dicha evocación. Fascinación, sorpresa, impermanencia junto con perdurabilidad en la memoria sensorial y emocional es lo que conmociona en el rito teatral (Ortolani, 1995: 302). Y esa conmoción puede alcanzar hasta la experimentación de lo absoluto, por la que un paisaje no representado sobre el escenario llegue a cabal presencia para convertirse en intemporal escenario del acontecer humano.

El teatro chino no concentra tanta energía como el japonés en la palabra. Sin embargo persigue un objetivo semejante, que consiste en trasladar a la mente del espectador una ilusión poética de base emocional (yijing). La síntesis entre la palabra -dicha o cantada- la gestualidad, el movimiento y la danza, y la apariencia -maquillaje y vestuario- pudiera traducirse en la idea wagneriana de totalidad. Pero cualquier propósito de mímesis, aun idealizada, es ajeno a la dramática china. Más próximo al modo griego de la enargeia, lo que procura es suscitar un reflejo subjetivo de la emoción que traslade el espíritu del personaje al público (shensi). Esto es lo que se considera verdad dramática, que no precisa de la similitud (Jingsong Chen, 1997). En la apariencia, el teatro chino guarda parecido con el teatro visual ${ }^{16}$. Pero sería imposible aplicarle la crítica que Baudrillard elaboró para la cultura actual de la visualidad, que concluye en la desilusión. Si el teatro es emoción, como quiere Alonso de Santos, no se puede prescindir de la ilusión. Y en este punto, el teatro oriental guarda aún mucha enseñanza ignorada en Occidente.

13 Anotación de junio de 1983, tras una representación en Lyon.

14 Reacciones que describe Fischer-Lichte (2011) en varios capítulos de su obra, deteniéndose sobre todo en performances de Abramovic o Beuys.

15 «Lo sagrado se convirtió en profano», anota Jan Fabre en su diario el 7 de marzo de 1983 (Fabre, 2017: 154).

16 De hecho el teatro visual de Robert Wilson realizado en espacios naturales se inspira en el ancestral teatro antropológico chino (nuoxi), con el que ni siquiera la Revolución Cultural pudo acabar. 


\section{BIBLIOGRAFÍA}

Álvarez Romero, María (2015). La escenografía del pensamiento [Trabajo de Fin de Grado inédito]. Universidad de Sevilla: Sevilla.

Baudrillard, Jean (2006). El complot del arte. Ilusión y desilusión estéticas. Buenos Aires: Amorrortu.

Bologna, Corrado (2017). El teatro de la mente. De Giulio Camillo a Aby Warburg. Madrid: Siruela.

Campioni, Giuliano (2007). Fisiología de la ilusión y de la décadence: el problema del actor y del teatro en Nietzsche y Wagner. Estudios Nietzsche, 7, pp. 3754. https://doi.org/10.24310/EstudiosNIETen.vi7.10268

Fabre, Jan (2017). Diario nocturno (19781984). Madrid: Casimiro Libros.

Fischer-Lichte, Erika (2011). Estética de lo performativo. Madrid: Abada.

Gil Fernández, Luis (2012). Aristófanes. Madrid: Gredos.

Gombrich, Ernst H. (2008). Arte e ilusión. Estudio sobre la psicología de la representación pictórica. New York: Phaidon.
González, Aurelio (2007). Ilusión y engaño en el teatro cervantino. En Germán Vega García-Luengos y Rafael González Cañal (eds.). Locos, figurones y quijotes en el teatro de los Siglos de Oro: Actas selectas del XII Congreso de la Asociación Internacional de Teatro Español y Novohispano de los Siglos de Oro. Ciudad Real: Ediciones de la Universidad de CastiIla-La Mancha. pp. 207-219.

Jingsong, Chen (1997). To Make People Happy, Drama Imitates Joy: The Chinese Theatrical Concept of Mo. Asian Theater Journal, 14 (1), pp. 38-55. https://doi.org/10.2307/1124084

Kantor, Tadeusz (2010). Teatro de la muerte y otros ensayos (1944-1986). Barcelona: Alba.

Martínez Luna, Sergio (2016). La cultura visual contemporánea y la cuestión de la materialidad. Imágenes, mediaciones, figuralidad. Escritura e imagen, 12 , pp. 93-111. https://doi.org/10.5209/ ESIM.54032

Nieto Nuño, Miguel (1998). Teatro y cine: Esquilache. En Natividad Cristina Carreras Lario y Celia Crespo Gámez (coords.). Cien años de cine: la fábrica y los sueños. Sevilla: Universidad de Sevilla, pp. 311-321.

Ortolani, Benito (1995). The Japanese theater. From shamanistic ritual to contemporary pluralism. Princeton: Princeton University Press.

Parmeggiani, Marco (2003). El concepto de ilusión en Schopenhauer y Nietzsche. Estudios Nietzsche, 3, pp. 43-66. https://doi.org/10.24310/EstudiosNIETen.vi3.9109

Prévand, Jean-François (2018). Voltaire / Rousseau: la disputa. Lleida: Milenio Publicaciones.

Teixeira de Souza, Ana Aparecida (2018). El fingimiento de la identidad y la ilusión teatral en Los baños de Argel de Cervantes. Hipogrifo. Revista de literatura y cultura del Siglo de Oro, 6 (1), pp. 205-215. https://doi.org/10.13035/H.2018.06.01.15

Valiente, Pedro (2000). Estudio del proceso de creación de la obra de Robert Wilson [Tesis doctoral inédita]. Universidad Complutense de Madrid: Madrid.

Wang Shifu (2002). Historia del ala oeste. En Alicia Relinque Eleta (ed. y trad.). Tres dramas chinos. Madrid: Gredos. 